\title{
ANALISIS KUALITAS FISIK DAN BAKTERIOLOGI (E-Coli) AIR SUMUR GALI DI JORONG KOTO KACIAK KANAGRIAN MAGEK KECAMATAN MAGEK
}

\author{
Mila Sari ${ }^{1}$, Syukra Alhamda ${ }^{2}$, Nova Herawati ${ }^{2}$ \\ ${ }^{1}$ Universitas Fort De Kock Bukittinggi \\ ${ }^{2}$ Poltekkes Kemenkes Padang
}

\begin{abstract}
Jorong Koto Kaciak is a fairly high incidence of diarrhea contributed 36\% of the incidence of diarrhea in Magek District. This study aims to analyze the Physical Quality and Bacteriology (E-Coli) of Dug Well Water in Jorong Koto Kaciak. This is a descriptive describing the physical quality and bacteriology of community dug well water. The populations were all community dug wells amount 153 units. By using cluster sampling, the sample was determined as much as 5 dug wells. Data collection used observation sheets and data analysis included univariate analysis which was carried out computerized. The results showed that $80 \%$ dug well water samples met the physical parameter requirements based on temperature, overall $100 \%$ community dug well water met the turbidity requirements $<25$ NTU / $100 \mathrm{ml}, 60 \%$ dug well water samples met the physical requirements. odorless and tasteless and overall $100 \%$ dug well water samples do not meet the quality requirements of microbiology (e-coli)> $50 \mathrm{MPN} / 100 \mathrm{ml}$ It can be concluded that the community dug well water physically meets the quality standard requirements drinking water, but microbiologically it does not meet the health standard requirements, especially the quality of bacteriology, which can increase the risk of gastrointestinal infections for the community (diarrhea). For this reason, it is recommended that the community and health workers in Jorong Koto Kaciak pay more attention to the quality of dug well water.
\end{abstract}

Keywords: physical quality; bacteriology; water; dug wells

\begin{abstract}
Abstrak
Jorong Koto Kaciak merupakan salah satu Jorong dengan angka kejadian diare yang cukup tinggi dimana pada tahun tercatat bahwa menyumbang 36\% kejadian diare di Kecamatan Magek, kondisi ini mengindikasikan kurang baiknya kualitas air konsumsi masyarakat di Jorong Koto Kaciak. Penelitian ini bertujuan untuk menganalisis Kualitas Fisik dan Bakteriologi (E-Coli) air sumur gali di Jorong Koto Kaciak. Jenis penelitian ini adalah penelitian deskriptif. Populasi pada penelitian ini seluruh sumur gali masyarakat di Jorong Koto Kaciak yaitu sebanyak 153 unit. Pengambilan sampel menggunakan teknik cluster sampling sehingga ditetapkan sampel sebanyak 5 sumur gali. Pengumpulan data menggunakan lembar observasi dan analisis data meliputi analisis univariat. Hasil penelitian menunjukkan bahwa sebagian besar (80\%) sampel air sumur gali memenuhi syarat parameter fisik berdasarkan suhu, secara keseluruhan (100\%) air sumur gali masyarakat memenuhi syarat kekeruhan < 25 NTU/ 100 ml, 60\% sampel air sumur gali memenuhi syarat fisik tidak berbau dan tidak berasa serta secara keseluruhan (100\%) sampel air sumur gali tidak memenuhi syarat kualitas mikrobiologi (e-coli) > 50 MPN/ $100 \mathrm{ml}$ Dapat disimpulkan bahwa air sumur gali masyarakat secara fisik telah memenuhi syarat standar kualitas air minum, namun secara mikrobiologi belum memenuhi syarat standar kesehatan terutama kaualitas bakteriologi (e-coli), yang dapat meningkatkan resiko infeksi saluran pencernaan bagi masyarakat (diare). Untuk itu disarankan kepada masyarkat dan petugas kesehatan di Jorong Koto Kaciak untuk lebih memperhatikan kualitas air sumur gali.
\end{abstract}

Kata kunci: kualitas fisik; bakteriologi; air, sumur gali 


\section{PENDAHULUAN}

Sumur gali merupakan salah satu sumber penyediaan air bersih bagi masyarakat di pedesaan maupun perkotaan. Sumur gali menyediakan air yang berasal dari lapisan tanah yang relatif dekat dengan permukaan tanah, oleh karena itu mudah terkontaminasi melalui rembesan yang berasal dari kotoran manusia, hewan, maupun untuk keperluan domestik rumah tangga. ${ }^{1,2}$ Sumber air sangat dibutuhkan untuk dapat menyediakan air yang baik dari segi kuantitas dan kualitasnya. Di Indonesia, umumnya sumber air minum berasal dari air permukaan (surface water), air tanah (ground water), dan air hujan. Termasuk air permukaan adalah air sungai dan air danau, sedangkan air tanah dapat berupa air sumur dangkal, air sumur dalam, maupun mata air. ${ }^{2-4}$

Menurut WHO (2013) definisi air adalah air yang digunakan untuk kebutuhan rumah tangga, minum, memasak dan higyene personal. Peraturan Menteri Kesehatan Republik Indonesia nomor 492/ Menkes/Per/IV/2010 yang mengatur tentang persyaratan kualitas air minum menyebutkan bahwa yang dimaksud air minum adalah air yang melalui proses pengolahan atau tanpa proses pengolahan yang memenuhi syarat kesehatan dan dapat langsung diminum. Air minum yang aman bagi kesehatan adalah yang memenuhi persyaratan fisika, mikrobiologis, kimiawi, dan radioaktif. ${ }^{2,5}$

Survei awal yang dilakukan di Jorong Koto Kaciak merupakan wilayah yang penduduknya pada umumnya masih menggunakan air sumur gali dalam penyediaan air bersih sehari - harinya. Hal ini disebabkan oleh karena belum semua masyarakat di daerah tersebut memperoleh air sebagai sumber air bersih maupun air minum. Berdasarkan hasil survei awal ke daerah tersebut, penulis melihat kondisi fisik air secara visual kelihatan jernih akan tetapi keberadaan sumur gali yakni jarak sumur gali terhadap sumber pencemaran masih sangat memprihatinkan, begitu juga dengan kondisi fisik sumur gali yang secara umum masih terlihat tidak memenuhi syarat sehingga mempunyai resiko tinggi terjadinya pencemaran kualitas air baik yang berasal dari jamban, sampah dan dari air buangan lainnya.

Berdasarkan hasil survei pendahuluan yang telah peneliti lakukan di Jorong Koto Kaciak, penulis mendapatkan informasi bahwa ada beberapa lokasi yang mengalami permasalahan mengenai air sumur berwarna kuning, mengeluarkan bau tak sedap seperti bau karat dan meninggalkan warna kuning pada bak mandi atau tempat penampungan air dari sumur. Selain itu, juga ditemukan keluhan masyarakat terkait kualitas air sumur yaitu air sumur menjadi keruh pada saat musim hujan, terutama setelah terjadi hujan lebat. Maka dari itu analisis penentuan kualitas air sangat penting dilakukan di Jorong Koto Kaciak sebagai informasi tentang keberadaan senyawa kimia yang terkandung dalam air yang dikonsumsi oleh masyarakat di Jorong Koto Kaciak. ${ }^{6-9}$ 
Peneliti juga melakukan wawancara dengan petugas kesehatan di Pustu Koto Kaciak, dari hasil wawancara tersebut peneliti memfokuskan topik pembicaraan tentang dampakdampak dari kondisi sumur galian masyarakat yang sangat berdekatan dengan areal persawahan dan sebagian besar dilalui oleh saluran irigasi persawahan, sehingga peneliti mendapatkan informasi bahwa dampak dari kondisi tersebut berupa angka kejadian penyakit yang berbasis lingkungan dimana ditemukannya kejadian diare yang termasuk kedalam 10 jenis penyakit terbanyak dan keluhan penyakit kulit yang juga banyak ditemukan di Jorong Koto Kaciak. Selain itu, penelitian juga mendapatkan informasi bahwa belum adanya dilakukan pemeriksaan kualitas sumber air bersih masyarakat di Jorong Koto Kaciak, khususnya kualitas sumber air dari sumur gali. Tujuan dari penelitian adalah untuk mengetahui kuliatas fisik dan bakteriologi air sumur gali yang ada di Jorong Koto Kaciak.

\section{METODE PENELITIAN}

Jenis penelitian ini adalah deskriptif dengan pendekatan studi kasus yaitu sebuah penelitian yang mencakup pengkajian suatu unit penelitian secara intensif, dalam hal ini adalah kualitas air sumur gali masyarakat di Jorong Koto Kaciak. Penelitian ini telah dilakukan di Jorong Koto Kaciak Kecamatan Kamang Magek Kabupaten Agam. Populasi dalam penelitian ini adalah seluruh masyarakat yang memiliki sumur gali sebagai sumber air bersih keluarga di Jorong Koto Kaciak Kecamatan Kamang Magek Kabupaten Agam yaitu sebanyak 153 sarana sumur gali. Pengambilan sampel pada penelitian ini menggunakan teknik cluster sampling yaitu suatu teknik pengambilan sampel berdasarkan sebaran wilayah sebaran populasi. Sehingga besaran sampel pada penelitian ini ditetapkan sebanyak 5 sampel air sumur gali yang diambil dari setiap dusun yang ada di Jorong Koto Kaciak, yaitu dusun Kampuang Jambak, Kampuang Baru, Ateh Bonjo, Surau Gadang dan Surau Baru. ${ }^{5}$ Data pada penelitian ini diperoleh dari sumur gali melalui pengukuran langsung menggunakan instrument penelitian dan uji laboratorium untuk mengetahui jumlah kandungan bakteri coliform dilakukan di Laboratorium Sains Terapan Universitas Fort De Kock Bukittinggi. 


\section{HASIL PENELITIAN}

Berdasarkan hasil pengukuran sampel kualitas fisik dan bakteriologi di laboratorium UPTD Laboratorium Dinas Kesehatan Kota Bukittinggi didapatkan hasil sebagai berikut :

\begin{tabular}{|c|c|c|c|c|c|c|c|c|}
\hline \multirow[b]{2}{*}{ No } & \multirow[b]{2}{*}{ Parameter } & \multirow[b]{2}{*}{ Satuan } & \multirow{2}{*}{$\begin{array}{c}\text { Permenkes } \\
\text { No. } \\
\text { 492/Menkes } \\
\text { /Per/IV/201 } \\
0 \\
\end{array}$} & \multicolumn{5}{|c|}{ Sampel } \\
\hline & & & & $A$ & B & C & $D$ & $E$ \\
\hline A & Fisik & & & & & & & \\
\hline 1. & Suhu & ${ }^{0} \mathrm{C}$ & $\begin{array}{c} \pm 3^{0} \mathrm{C} \text { suhu } \\
\text { udara } \\
\left(24-30^{0} \mathrm{C}\right)\end{array}$ & 25 & 27 & 24 & 26 & 23 \\
\hline 2. & Kekeruhan & NTU & 25 & 0,82 & 1,91 & 17,7 & 9,12 & 4,69 \\
\hline 3. & Bau dan rasa & - & $\begin{array}{c}\text { Tidak } \\
\text { berbau dan } \\
\text { tidak berasa }\end{array}$ & $\begin{array}{c}\text { Tidak } \\
\text { Berba } \\
\text { u dan } \\
\text { berasa }\end{array}$ & $\begin{array}{c}\text { Tidak } \\
\text { Berba } \\
\text { u dan } \\
\text { berasa }\end{array}$ & $\begin{array}{l}\text { Berba } \\
\text { u dan } \\
\text { berasa }\end{array}$ & $\begin{array}{l}\text { Berba } \\
\text { u dan } \\
\text { berasa }\end{array}$ & $\begin{array}{l}\text { Tidak } \\
\text { Berba } \\
\text { u dan } \\
\text { berasa }\end{array}$ \\
\hline B & Bakteriologi & & & & & & & \\
\hline 1. & $\begin{array}{c}\text { e-colli } \\
\text { (colliform) }\end{array}$ & $\begin{array}{c}/ 100 \\
\mathrm{ml}\end{array}$ & 0 & $>2400$ & $>2400$ & $>2400$ & 460 & $>2400$ \\
\hline
\end{tabular}

Berdasarkan tabel. 1 di atas bahwa ditemukan 1 sampel air sumur gali dengan suhu tidak memenuhi syarat yaitu $23^{\circ} \mathrm{C}$ sementara suhu air sumur gali yang memenuhi syarat menurut Permenkes No. 492/MenKes/Per/IV/2010 adalah $\pm 3^{0} \mathrm{C}$ suhu udara atau sekitar $24^{\circ} \mathrm{C}-30^{\circ} \mathrm{C}$ pada dataran tinggi. Sedangkan untuk kekeruhan secara keseluruhan sampel air sumur gali memenuhi syarat $<25$ NTU. Kualitas fisik bau dan rasa ditemukan sebanyak 2 sampel air sumur gali yang tidak memenuhi syarat dimana ditemukan sampel dengan yang berbau dan berasa besi. Untuk kualitas bakteriologi ditemukan secara keseluruhan sampel dengan kandungan coliform tidak memenuhi syarat yaitu $>50$.

\section{PEMBAHASAN}

\section{A. Analisis Kualitas Fisik Air Sumur Gali}

\section{Suhu}

Berdasarkan hasil penelitian diketahui bahwa dari 5 sampel air sumur gali, ditemukan sebagian besar $(80 \%)$ responden dengan kualitas fisik berdasarkan suhu memenuhi syarat dan hanya 1 sampel (20\%) responden dengan suhu tidak memenuhi syarat yaitu $< \pm 3^{\circ} \mathrm{C}$ suhu udara sekitar $\left(24-30^{\circ} \mathrm{C}\right)$.

Temperatur air akan mempengaruhi penerimaan masyarakat akan air tersebut dan dapat pula mempengaruhi reaksi kimia dalam pengolahannya terutama apabila temperature sangat tinggi. Temperatur yang diinginkan adalah $\pm 3^{0} \mathrm{C}$ suhu udara disekitarnya yang dapat memberikan rasa segar, tetapi iklim setempat atau jenis dari sumber-sumber air akan mempengaruhi temperatur air. Disamping itu, temperatur pada air mempengaruhi secara langsung toksisitas banyaknya bahan kimia pencemar, 
pertumbuhan mikroorganisme, dan virus. Temperature atau suhu air diukur dengan menggunakan termometer air. ${ }^{10,11}$

Suhu air berperan penting dalam menentukan kecepatan reaksi penguraian bahan organik maupun anorganik yang terlarut, mempengaruhi tingkat kelarutan garam-garam dan gas-gas dalam air terutama $\mathrm{O} 2$ yang berperan dalam proses metabolisme mikro maupun makroorganisme, serta gas $\mathrm{CO} 2$ sebagai salah satu komponen penting dalam proses fotosintesis yang menetukan produktivitas lingkungan perairan dan suplai oksigen terlarut. Standar baku suhu sumber air minum menurut Peraturan Menteri Kesehatan RI No. 492/MenKes/Per/IV/2010 yaitu $24-30^{\circ} \mathrm{C} .^{12,13}$ Hasil penelitian ini sejalan dengan penelitian yang telah dilakukan oleh Umar (2014) dengan judul gambaran kualitas air sumur gali di sekitar TPA Sumompo Kecamatan Tuminting Kota Manado, didapatkan hasil bahwa sebahagian besar kualitas parameter fisika suhu air sumur gali memenuhi syarat yaitu sebesar $88,88 \%$ sampel. $^{14}$

Menurut asumsi peneliti, sebagian besar air sumur gali di Jorong Koto Kaciak telah memenuhi syarat standar suhu air konsumsi masyarakat yaitu berkisar antara $24-30$ ${ }^{0} \mathrm{C}$, sedangkan pada penelitian ini secara umum ditemukan ditemukan bahwa rata-rata suhu air sumur gali masyarakat di Jorong Koto Kaciak adalah $25,2^{\circ} \mathrm{C}$. Namun pada penelitian ini ditemukan 1 sampel air sumur gali dengan kualitas fisik berdasarkan suhu tidak memenuhi syarat yaitu dengan suhu $23^{\circ} \mathrm{C}$ berada di bawah standar suhu minimal air sumur gali. Kondisi ini terjadi akibat kondisi bibir sumur yang kurang terawat sehingga banyak terdapat rumput-rumput yang menutupi bibir sumur sehingga sumur tidak terkena cahaya matahari serta kondisi dinding sumur yang terdiri dari lapisan tanah liat berwarna hitam dan selalu basah sehingga mempengaruhi suhu air sumur gali.

Suhu air yang terlalu dingin dapat memberikan dampak negatif terhadap kesehatan masyarakat, dimana air dengan suhu yang terlalu rendah yaitu di bawah standar suhu minimal air konsumsi menandakan air kurang atau tidak terkena sinar matahari dan menandakan larutan oksigen di dalam air sangat tinggi. Kondisi ini meningkatkan kemampuan berkembangnya flora dan fauna akuatis air (mikrobiologi), termasuk meningkatkan perkembangan bakteri-bakteri (coli from, e coli) di dalam air akibat terlalu tingginya kandungan oksigen dalam air yang dapat meningkatkan resiko infeksi (diare) jika dikonsumsi oleh manusia. Sedangkan suhu air yang terlalu hangat juga memberikan efek negatif bagi kesehatan manusia, dimana suhu yang terlalu hangat akan meningkatkan reaksi dan pelarian zat-zat kimia dan garam (kalsium) sehingga kualitas airpun menjadi tidak baik untuk dikonsumsi.

\section{Kekeruhan}

Hasil penelitian menunjukkan bahwa dari 5 sampel air sumur gali ditemukan secara keseluruhan sumur gali dengan tingkat kekeruhan memenuhi syarat yaitu dengan rata- 
rata laruhan partikel dalam air sebesar 6,84 NTU, sedangkan standar baku menurut menurut Permenkes RI No. 492/MenKes/Per/IV/2010 adalah 25 NTU.

Air dikatakan keruh apabila air tersebut mengandung begitu banyak partikel bahan yang tersuspensi sehingga memberikan warna/rupa yang berlumpur dan kotor. Bahanbahan yang menyebabkan kekeruhan meliputi lumpur, bahan-bahan organik yang tersebut secara baik dan partikel-partikel yang tersuspensi lainnya. Nephelometer adalah suatu alat untuk mengukur kekeruhan yang memberikan hasil dalam satuan Nephelometric Turbidity Unit (NTUs). NTUs adalah satuan standar untuk mengukur kekeruhan. Pada nephelometri dan turbidimetri, sumber cahaya diproyeksikan melalui sampel cairan yang disimpan dalam wadah sampel transparan. Umumnya, nephelometri menggunakan sumber cahaya yang memiliki panjang gelombang relatif singkat (misalnya, $500 \mathrm{~nm}-800 \mathrm{~nm}$ ) dan efektif digunakan untuk mendeteksi partikel dengan ukuran sangat kecil. Sedangkan, turbidimetri umumnya menggunakan sumber cahaya yang memiliki panjang gelombang lebih panjang (misalnya, $800 \mathrm{~nm}-1100 \mathrm{~nm}$ ) dan efektif digunakan untuk mendeteksi partikel dengan ukuran yang lebih besar. Jika seberkas cahaya dilewatkan melalui sampel keruh, intensitasnya dikurangi dengan hamburan, dan jumlah cahaya yang tersebar tergantung pada konsentrasi dan distribusi ukuran partikel. Dalam nephelometri intensitas cahaya yang tersebar diukur, sedangkan dalam turbidimetri, intensitas cahaya yang ditransmisikan melalui sampel diukur ${ }^{13}$.

Hasil penelitian ini sejalan dengan penelitian terdahulu yang telah dilakukan oleh Wulan (2016) dengan judul Analisis kualitas air sumur masyarakat Kelurahan Lalolara Kecamatan Kambu (Studi Kasus Air Sumur Warga Kelurahan Lalolara) didapatkan hasil bahwa sebagian besar $75 \%$ sampel air sumur gali dengan kekeruhan $<25$ NTU (memenuhi syarat) $^{15}$

Menurut asumsi peneliti secara mayoritas air sumur gali masyarakat di Jorong Koto Kaciak memiliki kualitas fisik berdasarkan kekeruhan telah memenuhi standar baku air minum dengan tingkat kekeruhan < 25 NTU. Berdasarkan hasil penelitian diketahui bahwa secara keseluruhan terlihat sampel air sumur gali masyarakat di Jorong Koto Kaciak terlihat jernih dan tidak keruh. Kondisi ini dipengaruhi oleh kondisi dinding dan jenis tanah sumur gali yang ada di Jorong Koto Kaciak, dimana secara umum sumur gali yang ada di Jorong Koto Kaciak adalah sumur dengan bibir yang dilapisi oleh beton semen dan hanya ada 1 sumur yang tidak memiliki bibir dari semen karena kondisi tanah dinding yang kokoh dan keras sehingga tidak memiliki resiko untuk longsor. Kondisi ini mengurangi resiko masuknya atau terkontaminasinya air sumur gali oleh bahan-bahan pencemar dari luar yang dapat menjaga tingkat kekeruhan air dalam skala normal yaitu $<25$ NTU. 
Air yang keruh menandakan bahwa banyaknya partikel bahan yang tersuspensi sehingga memberikan warna/rupa yang kotor, tingginya bahan-bahan organik yang tersebar dari partikel-partikel kecil yang tersuspensi mengurangi kualitas air sehingga air tidak baik untuk dikonsumsi, karena akan partikel yang tinggi akan memberikan dampak negatif terhadap kesehatan masyarakat.

\section{Bau dan Rasa}

Hasil penelitian menunjukkan bahwa dari 5 sampel air sumur gali pada penelitian, ditemukan lebih dari sebahagian yaitu sebanyak 3 sampel $(60 \%)$ air sumur gali dengan kualitas fisik bau dan rasa memenuhi syarat yaitu air tidak berbau dan tidak berasa. Serta ditemukan kurang dari sebahagian (40\%) sampel air sumur gali yang tidak memenuhi syarat dimana air terasa tidak tawar (rasa karat) dan mengeluarkan aroma yang khas.

Bau dan rasa biasanya terjadi secara bersamaan dan biasanya disebabkan oleh adanya bahan-bahan organik yang membusuk, tipe-tipe tertentu organisme mikroskopik, serta persenyawaan-persenyawaan kimia seperti phenol. Bahan-bahan yang menyebabkan bau dan rasa ini berasal dari berbagai sumber. Intensitas bau dan rasa dapat meningkat bila terdapat klorinasi. Karena pengukuran bau dan rasa ini tergantung pada reaksi individu maka hasil yang dilaporkan tidak mutlak. Untuk standard air bersih sesuai dengan Permenkes RI No. 492/MenKes/Per/IV/2010 menyatakan bahwa air bersih tidak berbau dan tidak berasa. Hasil penelitian ini sejalan dengan penelitian terdahulu yang telah dilakukan oleh Wulan (2016) dengan judul Analisis kualitas air sumur masyarakat Kelurahan Lalolara Kecamatan Kambu (Studi Kasus Air Sumur Warga Kelurahan Lalolara) didapatkan hasil bahwa sebagian besar $75 \%$ sampel air sumur gali tidak berbau dan tidak berasa. ${ }^{15}$

Menurut asumsi peneliti secara umum kualitas fisik air sumur gali berdasarkan bau dan rasa di Jorong Koto Kaciak telah memenuhi syarat standar baku kesehatan yaitu air tidak berbau dan tidak berasa dimana air tidak mengeluarkan bau dan terasa tawar. Kondisi ini menunjukkan bahwa mayoritas air sumur gali di Jorong Koto Kaciak memiliki kualitas fisik berdasarkan bau dan rasa telah memenuhi syarat kesehatan. Namun pada penelitian ini masih ditemukan sebahagian air sumur gali yang tidak memenuhi syarat berdasarkan bau dan rasa yaitu sebanyak 2 sampel sumur (40\%) yaitu sampel sumur C dan sumur $\mathrm{D}$, dimana air memiliki rasa besi (karat) dan mengeluarkan aroma yang khas. Pada sumur $\mathrm{C}$ diketahui bahwa kondisi sumur gali yang terletak sangat berdekatan dengan area persawahan sehingga air genangan sawah yang bersifat asam (lumpur) mengendap dan meresap ke dinding sumur sehingga mencemari air sumur gali yang berada sangat berdekatan dengan area persawahan. Sedangkan pada sampel air sumur D diketahui bahwa diketahui bahwa air sumur gali yang berasa dan berbau khas karat 
dan besi disebabkan oleh penggunaan pipa yang terbuat dari besi yang digunakan untuk sambungan penyedot air menggunakan mesin, sehingga meningkatkan kadar larutan Fe yang ditandai dengan bau dan rasa khas karat yang tercium dari air sumur gali masyarakat.

Tingginya larutan besi ( $\mathrm{Fe}$ ) di dalam air konsumsi masyarakat menyebabkan kualitas air menjadi tidak baik untuk di konsumsi, dimana kandungan $\mathrm{Fe}$ yang tinggi dapat menyebabkan kerusakan pada dinding saluran cerna (usus), gangguan pada ginjal serta gangguan fungsi hati jika dikonsumsi dalam jangka waktu yang panjang karena larutan Fe yang tinggi bersifat korosif. Selain itu, air dengan kandungan Fe tinggi dapat menyebabkan iritasi pada mata dan kulit manusia.

\section{B. Analisis Kualitas Bakteriologi (e-coli) Air Sumur Gali}

Berdasarkan hasil penelitian yang telah dilakukan terhadap 5 sampel sumur gali masyarakat di Jorong Koto Kaciak diketahui bahwa secara keseluruhan (100\%) sampel sumur gali masyarakat di Jorong Koto Kaciak tidak memenuhi syarat maksimum mikrobiologi (e-coli) menurut Permenkes RI No. 492/MenKes/Per/IV/2010 yaitu maksimum 0 MPN/ $100 \mathrm{ml}$ atau tidak ditemukan kandungan bakteri coli form maupun ecoli, sedangkan rata-rata kandungan coliform/ e-coli air sumur gali masyarakat di Jorong Koto Kaciak adalah $2.012 \mathrm{MPN} / 100 \mathrm{ml}$.

Air untuk keperluan minum yang sehat dan hygienis harus bebas dari segala bakteri, kuman dan virus, terutama bakteri patogen. ${ }^{16}$ Bakteri golongan Coli (Coliform bakteri) tidak merupakan bakteri patogen, tetapi bakteri ini merupakan indikator dari pencemaran air oleh bakteri patogen. Menurut Permenkes RI No. 492/MenKes/Per/IV/2010, bakteri coliform yang memenuhi syarat untuk air bersih bukan perpipaan adalah 0 MPN. Standar air minum di Indonesia mengikuti standar WHO yang dalam beberapa hal disesuaikan dengan kondisi di Indonesia. Pada tahun 2010, Departemen Kesehatan RI telah menetapkan kriteria kualitas air secara mikrobiologis, melalui permenkes RI No 492/MenKes/Per/IV/2010 bahwa air minum tidak diperbolehkan mengandung bakteri coliform dan Escherichia coli. Escherichia Coli merupakan flora normal didalam usus manusia dan akan menimbulkan penyakit bila masuk kedalam organ atau jaringan lain. Dapat menimbulkan pneumonia, endocarditis,infeksi pada luka, abses pada berbagai organ, meningitis dan dapat menyebabkan penyakit diare. ${ }^{2,17}$

Hasil penelitian ini sejalan dengan penelitian terdahulu yang telah dilakukan oleh Yuliana (2016) dengan judul uji MPN bakteri escherichia coli pada air sumur berdasarkan perbedaan konstruksi sumur di wilayah Nagrak Kabupaten Ciamis didapatkan hasil bahwa secara keseluruhan (100\%) sumur gali dengan konstruksi non beton tidak memenuhi syarat kandungan e-coli yaitu $>50 \mathrm{mpn} / 100 \mathrm{ml}^{18}$ 
Menurut asumsi peneliti secara umum kualitas bakteriologi air sumur gali di Jorong Koto Kaciak tidak memenuhi syarat, yaitu air konsumsi masyarakat tidak dibolehkan mengandung bacterial feal e coli/ coli form, sedangkan di Jorong Koto Kaciak diketahui bahwa kandungan bakteriologi air sumur gali sangat tinggi yaitu dengan rata-rata $>2012$ MPN/ $100 \mathrm{ml}$ kondisi ini merupakan tantangan yang besar bagi masyarakat dan petugas kesehatan, karena kandungan coliform atau e-coli yang tinggi di dalam air minum akan meningkatkan resiko penyakit infeksi saluran pencernaan, salah satunya adalah diare.

Tingginya kandungan e-coli dan coliform pada air sumur gali masyarakat di Jorong Koto Kaciak dipengaruhi oleh kondisi fisik sumur yang sangat berdekatan dengan saluran irigasi dan areal persawahan sehingga pada saat hujan terjadi resapan air sawah dan air irigasi yang dapat mencemari air sumur gali. Selain itu, di Jorong Koto Kaciak juga banyak ditemukan sumur gali masyarakat memiliki jarak yang cukup dekat dengan septi tank yaitu kurang dari 10 meter serta limbah rumah tangga yang terlalu dengan dengan sumur gali. Kondisi ini meningkatkan resiko pencemaran air sumur gali oleh resapan septi tank maupun limbah rumah tangga yang akan meningkatkan pencemaran bakteriologi (e-colli) terhadap air sumur gali masyarakat. Tingginya kandungan bakteriologi (e-colli) di dalam sumber air minum masyarakat memberikan dampak negatif terhadap kesehatan, dimana bakteri e-colli merupakan salah agen penyebab infeksi saluran pencernaan, salah satunya adalah meningkatkan resiko kejadian diare dan penyakit infeksi saluran cerna lainnya. ${ }^{18,19}$

\section{SIMPULAN DAN SARAN}

Dari hasil penelitian didapatkan kesimpulan bahwa (80\%) air sumur gali masyarakat di Jorong Koto Kaciak memenuhi syarat kualitas fisik berdasarkan suhu yaitu $30^{\circ} \mathrm{C}$ suhu udara sekitar, tingkat kekeruhan yaitu < 25 NTU/ 100 ml, memenuhi syarat kualifas fisik bau dan rasa, dimana air sumur gali tidak berasa dan tidak berbau. Sedangkan pada kualitas bakteriologi tidak memenuhi syarat bakteriologi (e-coli) dengan kandungan e-colli air sumur gali masyarakat cukup tinggi yaitu dengan rata-rata 2012 MPN/ 100 ml. Disarankan agar masyarakat di Jorong Koto Kaciak untuk dapat memperhatikan syarat-syarat sumber air minum yang sehat yaitu dengan kualitas bakteriologis yang tidak memenuhi syarat akan menyebabkan penykit diare pada masyarakat sekitar.

\section{DAFTAR PUSTAKA}

1. Rizal R. Studi Kelayakan Lingkungan. Jakarta: EGC; 2016.

2. Aswar A. Ilmu Kesehatan Lingkungan. Jakarta. University of Indonesia Press; 2013.

3. Winni T. Analisis Kandungan Pb pada Air Sumur Gali Masyarakat di Sekitar Tempat Penimbunan Limbah Padat Industri Timah dari Daur Ulang Aki Bekas Desa Sei Rotan 
Kecamatan Sei Tuan Kabupaten Deli Serdang. J FKM Univ Sumatera Utara Medan. 2012;

4. Budiman C. Pengantar Kesehatan Lingkungan. Jakarta: EGC; 2007.

5. Nursalam. Metodologi Penelitian IImu Keperawatan. Jakarta: Salemba; 2013.

6. Dinkes Agam. Profil Dinas Kesehatan Kabupaten Agam. 2018.

7. Dinkes Agam. Profil Dinas Kesehatan Kabupaten Agam. 2017.

8. Nagari Magek. Profil Jorong Koto Kaciak Kenagarian Magek. 2018.

9. Puskesmas Magek. Profil Puskesmas Magek. 2018.

10. Fadilah R. Studi Kualitas Bakteriologis Air Sumur Gali Pada Kawasan Permukiman Menggunakan Biosensor TECTATM B16 Dusun Blimbingsari dan Dusun Wonorejo Kabupaten Sleman Yogyakarta. J Sains dan Teknol Lingkung UII. 2014;6(1).

11. Juli S. Kesehatan Lingkungan. Yogyakarta: Gajah Mada University Press; 2012.

12. Ni M M. Analisis Kandungan Pb pada Air Sumur Gali Masyarakat di Sekitar Tempat Penimbunan Limbah Padat Industri Timah dari Daur Ulang Aki Bekas Desa Sei Rotan Kecamatan Sei Tuan Kabupaten Deli Serdang. J PSKM FK Univ Udayana. 2008;

13. Sarman. Analisis Kualitas Air Sumur Dangkal Di Kawasan Pesisir Di Kelurahan Lemo Kecamatan Kulisusu Kabupaten Buton Utara. Kendari. Univ Halu Oleo. 2015;

14. Umar FR. Gambaran Kualitas Air Sumur Gali Di Sekitar Tpa Sumompo Kecamatan Tuminting Kota Manado Tahun 2014. 2014;(416):1-9.

15. Wulan. Analisis kualitas air sumur masyarakat Kelurahan Lalolara Kecamatan Kambu (Studi Kasus Air Sumur Warga Kelurahan Lalolara). 2016;

16. Tarigan S. Analisis Kualitas Air Sumur Gali Penduduk Dilihat Dari Parameter Fisik Dan Kimia Di Kelurahan Tanjung Selamat Kecamatan Medan Tuntungan Kota Medan. Medan. UNM Libr. 2016;

17. Marsono. Faktor - Faktor yang Berhubungan dengan Kualitas Bakteriologis Air Sumur Gali di Permukiman di Desa Karanganom Kecamatan Klaten Utara kabupaten Klaten. Univ Negeri Semarang.

18. Yuliana A. Uji Mpn Bakteri Escherichia Coli Pada Air Sumur Berdasarkan Perbedaan Konstruksi Sumur Di Wilayah Nagrak Kabupaten Ciamis. J Kesehat Bakti Tunas Husada J IImu-ilmu Keperawatan, Anal Kesehat dan Farm. 2016;16(1):1.

19. Ira A. Gambaran Kualitas Fisik dan Bakteriologis Air Serta Kondisi Fisik Sumur Gali di Kelurahan Bitung Karangria Kecamatan Tuminting Kota Manado. J KESMAS Univ Sam Ratulangi. 